\title{
Characterizations of natural dye from garcinia mangostana with graphene oxide (GO) as sensitizer in dye-sensitizer solar cells
}

\begin{abstract}
Usage of natural product in improvement of dye-sensitized solar cell (DSSC) have been look upon in research field. There is numerous different type of nature product was used as natural dye but the performance of DSSC with natural dye are low efficiency compare to DSSC with Ruthenium (II) dye due to low anchoring strength between dye molecule with $\mathrm{TiO} 2$ surface. This paper is about an experiment DSSC device with sensitizer of Mangosteen with Graphene Oxide as catalyst. The highest device efficiency with graphene oxide (GO) concentration of $0.50 \mathrm{mg} / \mathrm{ml}$ obtained in this experiment is $0.40 \%$ with short-circuit current density $(\mathrm{Jsc})=1.00 \mathrm{~mA} / \mathrm{cm} 2$, open circuit voltage $(\mathrm{Voc})=0.61 \mathrm{~V}$ and fill factor $(\mathrm{FF})=$ $65.72 \%$. It shows that GO helped to increase device performance by increase the ability of sensitizer absorbed onto $\mathrm{TiO} 2$ and adding more passageway for carriers movement between $\mathrm{TiO} 2$ surface and dye sensitizer.
\end{abstract}

Keyword: Graphene oxide; Natural dye; Dye-sensitized solar cell; Mangosteen sensitizer 